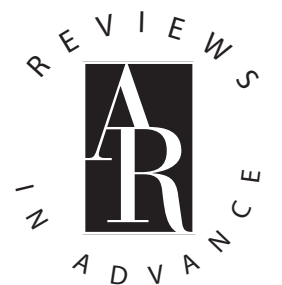

Review in Advance first posted online on May 31, 2017. (Changes may still occur before final publication online and in print.)

\title{
Language and the Newness of Media
}

\section{Ilana Gershon}

Department of Anthropology, Indiana University, Bloomington, Indiana 47405; email: igershon@indiana.edu

Annu. Rev. Anthropol. 2017. 46:15-31

The Annual Review of Antbropology is online at anthro.annualreviews.org

https://doi.org/10.1146/annurev-anthro-102116041300

Copyright (c) 2017 by Annual Reviews. All rights reserved

\section{Keywords}

language, media, participant structure, newness, coordination, social change

\begin{abstract}
How is the newness of new media constructed? Rejecting technological determinism, linguistic anthropologists understand that newness emerges when previous strategies for coordinating social interactions are challenged by a communicative channel. People experience a communicative channel as new when it enables people to circulate knowledge in new ways, to call forth new publics, to occupy new communicative roles, to engage in new forms of politics and control-in short, new social practices. Anthropologists studying media have been modifying the analytical tools that linguistic anthropologists have developed for language to uncover when and how media are understood to provide the possibilities for social change and when they are not. Taking coordination to be a vulnerable achievement, I address recent work that elaborates on the ways that linguistic anthropology segments communication to explore how a particular medium offers its own distinctive forms of authorship, circulation, storage, and audiences.
\end{abstract}




\section{INTRODUCTION}

I open with an insight from Barney Bate, a friend who died in March 2016 and is deeply missed by many. A linguistic anthropologist and Tamil scholar, Barney Bate was fascinated by the newness of what other scholars viewed as old media. He turned to political oratory and showed how, in Tamil-Nadu from 1840 to 1920, public speeches functioned, for all intents and purposes, as new media. They circulated knowledge in new ways and called forth new publics, new communicative roles, and new forms of politics and control—in short, new social practices. In referring to political speeches uttered in the 1910s as a "new communicative medium" (Bate 2013, p. 145), Bate provides the starting point for this review: The newness of new media lies not in the technology, but in the sociomaterial practices that linguistic anthropologists' analytical concepts render visible.

Bate understood that to communicate is also to coordinate- to coordinate with others how utterances entail and presuppose contexts, roles, strategies, and beliefs. Today, more types of communicative channels are available than ever before, each medium supplying its distinctive way to coordinate forms of authorship, circulation, storage, and audiences. This rapid proliferation has led scholars from a number of disciplines to wonder about the newness of new media—asking how newness is constructed in different contexts, which aspects of newness are significant, and how this constructed newness intersects with social changes (Chun \& Keenan 2006, Gitelman 2006, Marvin 1988, Peters 1999, Silverstone 1999, Thorburn \& Jenkins 2003). Various forms of technological determinism haunt these analyses, recognized as pitfalls to be assiduously avoided. Linguistic anthropologists also view newness as constructed (Urban 2001) and segment the coordination that media demands using a range of conceptual tools and questions developed initially to study language. Their commitment to understanding communicative interactions as vulnerable achievements helps shape the kind of coordination they focus on when analyzing media. I provide a take on a different set of literature than offered by recent Annual Review of Antbropology overviews of new media (Coleman 2010, Nardi 2015, Wilson \& Peterson 2002) by further developing Barney Bate's insight that the newness of new media lies in forms of coordination that can be addressed with rigor by linguistic anthropologists and their intellectual interlocutors.

If one takes media to be primarily channels of communication, then each medium is distinctive in enabling some participant structures-the "structural arrangements of interactions" (Philips 1972, p. 306) - rather than others. Participant structure involves the range of roles available in a communicative interaction and how participation in these roles is organized. By turning to Philips's version of participant structure, scholars are able to move away from the centripetal pull toward presuming dyadic relationships present in Roman Jakobson's model or some readings of Goffman's participant framework (Goffman 1974, 1981; Irvine 1996; Jakobson 1960; Levinson 1988). Every new communicative channel alters the available participant structures that have previously been established for already existing channels, however slightly (Peters 1999). As Peters argues, every new medium changes the possibilities by which one can have dialogic conversations or broadcast utterances and, in doing so, reframes how people will understand older media's position on an ever-revised continuum between dyadic conversation and one-to-many communication (Peters 1999). These changes are not the only way that a medium's participant structure affects how communication is coordinated, nor is media the only agentive element. The changes also affect how people align utterances with identities (Baron 2002, Bauman 2010a, Kunreuther 2014), utterances or texts with contexts (Bauman \& Briggs 1990, Deger 2013, Eisenlohr 2010, Laurier 2001, Weilenmann 2003), stances with stance objects (Walton \& Jaffe 2011), registers or genres with communicative channels (Doostdar 2004, Ferrara et al. 1991, Squires 2010), or pragmatics with metapragmatics (Briggs 2011, Tannen 2013).

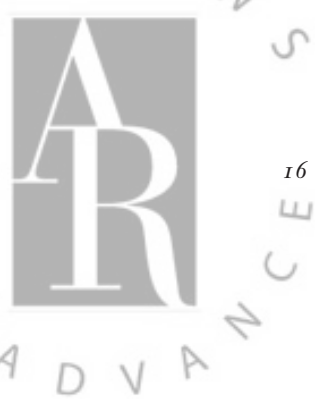

Gershon 
When a medium shifts an interaction's participant structure, this potentially disrupts how identities are repeatedly normalized. It troubles the ease with which people assume the predictability and intelligibility of utterances, done by linking these utterances to the communicative roles of that interaction. Such alignments presuppose forms of identity that putatively span all contexts (see Lempert \& Silverstein 2012, Mendoza-Denton 2011, Wortham 2003). Linguistic anthropologists understand that it takes effort to unite the many ways in which people interact with others in multiple contexts under the rubric of a defined identity. When identities are viewed as spanning contexts, participant structures that challenge how one establishes one's identity in a context make potentially visible the fragility of established identities, as evident in research that focuses on how new participant structures challenge previously stabilized gender and racial identities (Bucholtz \& Hall 2005). With a new medium, participants must determine ways to extend their assumptions about how communication should take place to this new participant structure (Archambault 2013). Introducing a new medium is not inherently a transformative moment (Baron 2002, Bauman 2010a, McIntosh 2010). In Bauman's analysis of US early commercial sound recordings about rural or migrant telephone use from the 1890s to 1910s, the recording's humor revolves around demonstrating that elites are more flexible than others in successfully incorporating these new forms into their communicative repertoire, thus legitimating established social hierarchies (Bauman 2010a). Others explore ethnographic situations in which concepts of the self were contested, and a new medium became a welcome (if serendipitous) means for people to shape influential new versions of the self (Ahearn 2001, Inoue 2011, Kunreuther 2014). As Mazzarella points out, it is often difficult to determine if a new technology will be revolutionary or reactive because, with new media, "transformation often comes masked as repetition" (Mazzarella 2010, p. 798; see also Strathern 2014 for similar insights about academic innovation). In short, media's potential depends on how people are coordinating utterances, participant structures, and larger identity constructs and not on the technological structure of the media or how recently it was invented.

Developing techniques for coordinating utterances or texts with contexts also makes visible a medium's novelty. Scholars recognize that mobile phones create the possibility of unratified listeners or awkwardly accessible callees, leading their users to openly coordinate information about their spatial contexts in ways that landline conversations did not include (Laurier 2001, Weilenmann 2003). Other authors view entextualization-the processes by which texts are constructed to be disembedded from one context and then re-embedded in other contexts-as integral to the experience of newness (Androutsopoulos 2014, Bauman \& Briggs 1990, Jones 2009). Raclaw et al. describe how mobile phones allow Americans to introduce entextualized snippets of texted conversations into in-person conversations. Once the snippet is introduced, then people's shared media ideologies about how the phone influences the epistemological standing of the text will help to coordinate interpretations of the re-entextualized utterance (Raclaw et al. 2016). Eisenlohr points out that as texts circulate through different media, participants will often value some media as providing a more immediate or less mediated sense of that which the text represents. Perhaps counterintuitively, older media are not necessarily seen as more authentic or transparent. In Eisenlohr's (2011b) example, Mauritian Muslims value the perceived immediacy of cassette tapes more than written texts. Experiences of entextualization often also pose implicit comparisons between mediated representations of so-called reality or, in other examples, mediated connections to divinity (Eisenlohr 2011a, Oosterbaan 2011, Strassler 2014).

When participant structures change, so too do the possibilities for stance-taking, the "taking up a position with respect to the form or content of one's utterance" (Jaffe 2009, p. 3). People consciously use the possibilities offered by media to signal their epistemological or affective stances to their utterances. In their analysis of the blog Stuff That White People Like, Walton \& Jaffe (2011) show how this blog enabled white people in the United States to adopt new forms of reflexivity

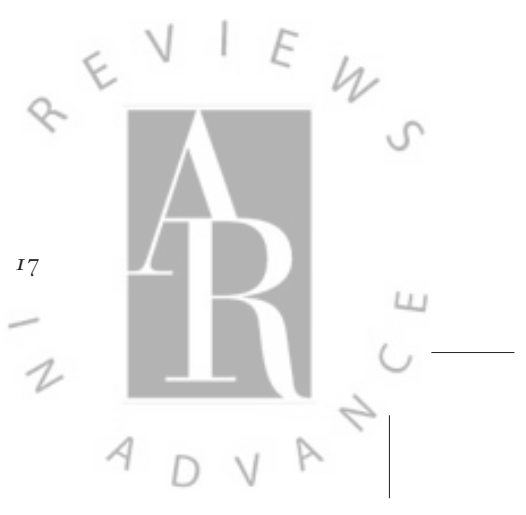


toward their identity, facilitating an ironic alignment with an identity marked as both white and explicitly ethnic. Englund describes how radio grandfathers were able to assert hierarchical relationships through their strategies for interweaving others' voices throughout their broadcasts. They engaged with both radio callers and prerecorded conversations in bureaucratic offices and on the streets, and by controlling how others' voices were interwoven into their broadcast, they positioned themselves as authoritative, a stance vis-à-vis others' words that was newly made possible by radio (Englund 2015).

When newness is being produced, the pragmatic and metapragmatic need not be so tightly coordinated. Squires explains that media can be taken as new when people begin to associate a "socially recognized register of forms" (Agha 2003, p. 231) with a given medium, regardless of how users in fact communicate through that medium. That is, claims about how the Internet changes language reveal far more about what people believe about how technology creates new registers and often reveals little about whether the registers actually exist, or the forms they take (Squires 2010). In a similar move, media historian Sterne points out that Americans listening to early phonographs often believed that it allowed the voices of the dead to speak to posterity, despite the fact that contemporary recordings were too fragile to last beyond several playings and thus could only convey the voices of the departed in constrained instances, such as when a minister recorded a sermon on his deathbed (Sterne 2003). Briggs discusses how when utterances travel across media with different participant structures, an incongruity between pragmatic and metapragmatic use of mediatized objects can become noticeable. In these moments, the incongruity is often attributed to errors, distortions, ignorance, sensationalism, or bad faith on the part of particular actors, instead of being seen as "structural and expected" (Briggs 2011, p. 221), because those involved overlook the kinds of coordination that switching participant structures requires (Briggs 2011).

In short, when an introduced medium changes the participant structure of communication, people are often encouraged to take communicative forms explicitly as potentially changeable as they try to accomplish social tasks. Part of experiencing newness, thus, is being encouraged to take a reflexive and strategic stance to how communication does or does not recreate social assumptions. Yet, as Sterne cautions, media do not always precede media beliefs. Some technologies come into being only because culturally and historically specific understandings of how communication takes place enable people to conceive of that technology in the first place (Sterne 2003, 2012).

\section{MEDIA IDEOLOGIES AND AFFORDANCES}

One way to discuss how each new channel encourages people to be reflexive about how communicative practices are coordinated is to analyze the channel's affordances, thereby emphasizing that media are also technology. The concept of affordances was initially introduced by the psychologist James Gibson to refer to what an object or part of an environment provides an animal "relative to the animal and commensurate with its body" (Gibson 1979, p. 150). For the purposes of this review, I turn to the usage adopted by Ian Hutchby, who altered Gibson's original definition of affordances to make it applicable to communicative technologies by deeming affordances as "the possibilities for action that it [the artifact] offers" (Hutchby 2001, p. 447). Often people's explicit social analysis of a medium's novelty revolves around reflections on the perceived affordances, for good or for ill. For example, deaf people were initially ambivalent about webcams because they had to start paying attention to their appearance, leading to a new sign: three-o'clock-inthe-morning-hair-sticking-up-chat (Keating \& Mirus 2003). Affordances can exist as a range of possibilities inherent in the material structure of the channel itself (Lemon 1998) —for example, writing viewed as a materialized sign, as Keane explains, can be "persistent, portable, perishable, alienable, and so forth" (Keane 2013, p. 2). Yet, as Lemon and Keane point out, which aspects 
of these affordances become relevant in a given situation or for a group of people is culturally specific; in Keane's example, how writing is perishable depends on widely held understandings of what it means to be perishable. Here, media ideologies, as a subset of semiotic ideologies, come into play (Gershon 2010b, Keane 2003).

Linguistic anthropologists have long found an analytical advantage in distinguishing between how people speak and what people believe about how speech functions. They describe people's beliefs, strategies, and attitudes about language as language ideologies (Silverstein 1979, Woolard \& Schieffelin 1994). This analytical distinction has also proven useful to anthropologists of media as they distinguish between the analyst's perspective on how media shape a message and what their fieldwork interlocutors believe. Scholars then explore how these beliefs influence but do not determine how people in practice communicate when using or avoiding media (Gershon 2010b, Henkin 2006, Lange 2014). Street (1984) cautions that anthropologists should pay careful attention not to project their own media ideologies onto others' practices when analyzing. Moreover, as Larkin (2008) illustrates, in colonial contexts, and indeed in any socially differentiated context, analysts should not restrict themselves to exploring only a single group's set of semiotic ideologies. Indeed, mistaken beliefs about others' media ideologies may illuminate how newness is understood and mobilized to reinforce inequalities. Larkin describes how British settlers projected onto Nigerians an experience of the shock of the new, in awe of Western technological prowess, when Nigerians were, in reality, blasé about moving images. The colonial mismatch in media ideologies reveals much about the systematic misunderstandings at the heart of colonial encounters (Larkin 2008).

Exploring the distinction between media ideology and practice has led to a strand of research on media ambivalence. These scholars examine how people's media ideologies lead them to try to control their own and others' use of particular channels (Hagood 2011, Spyer 2001, Umble 2000) and then to analyze the practices that spring up in response to these attempts because this control is always only partial (Ribak \& Rosenthal 2015). By focusing on media ambivalence, rather than, say, media resistance, scholars can trace how people's media ideologies intertwine with media practices fluidly as, over time, people take different positions about their media use as they negotiate the necessities of accomplishing specific social tasks (Ribak \& Rosenthal 2015).

Semiotic ideologies may all be mutually constituting, but they do not always align smoothly, especially when widespread assumptions about how a medium should be laminated with language have yet to be established. Taylor (2009) explores this notion in her analysis of the difficulty initially experienced by Hollywood filmmakers in the late 1920s when transitioning from silent films to talkies. There was a struggle to align voices with filmic images in ways that supported larger gender and ethnic stereotypes of what particular bodies should sound like, a struggle that redefined the qualities of a film star (Taylor 2009). In some instances, intertwined language and media ideologies function as traces of historical legacies (Hull 2012, Schulthies 2014, Sherouse 2014). For example, in the republic of Georgia, people believe that phone numbers should be spoken in Russian and will often code-switch between Georgian and Russian when telling someone a phone number. Although Georgians believe that speaking in Georgian would lead to callers miskeying the phone number, Sherouse (2014) did not find this to be the case in practice. Nor did he find that the ease Georgians ascribed to using Russian for phone numbers made sense phonetically or applied when discussing numbers in math classes. Using Russian for phone digits has been linked to how Georgians understand their modernity but is not linked, surprisingly, to a nostalgia or loyalty for the Soviet era (Sherouse 2014).

Others have focused on how people's beliefs about media shape what they understand a medium's affordances might be and thus shape the potential for transformation that a medium might introduce (Barker 2008, Larkin 2008, Umble 2000, Weidman 2006). People with Parkinson's understand the possibilities of creativity through the affordances in the virtual world

www.annualreviews.org • Language and the Newness of Media

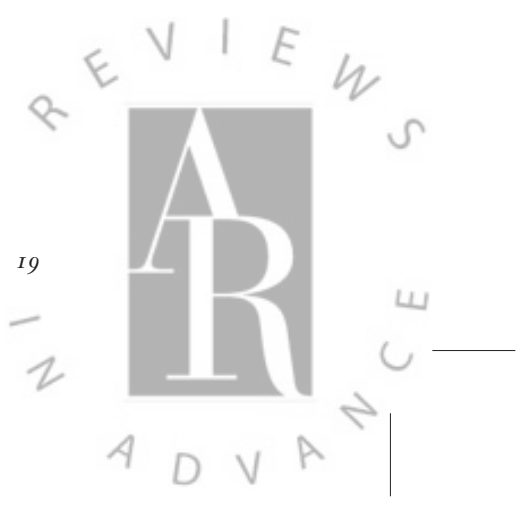


SecondLife as a way to have a different embodied experience of their physical body (Davis \& Boellstorff 2016). Scholars interested in how digital technologies have changed work relations find that analyzing media ideologies is a productive starting point for understanding how changes in workplaces affect people's efforts to sustain collegial networks, families, and friendships (Christensen 2009, Gregg 2011, Nardi 2005).

Others examine the ways changes in communicative channels generate disagreements about what this shift enables or transforms and how best to integrate newcomers into communities of practice (Lave \& Wenger 1991). Weidman (2006) describes how the introduction of the phonograph into South Indian classical music communities of practice led to considerable consternation over whether students could learn properly from records instead of a human guru. The debate centered around how people evaluated the phonographs' affordances. Some disparaged the phonograph as creating an inauthentic and untrustworthy experience of music by separating the musician's body from the sound. Others saw phonographs as valuably privileging hearing above all other senses and allowing listeners to ignore distracting information they might receive through the immersiveness of live performance. Although everyone agreed that the phonograph transformed the experience of learning Indian classical music, the community's media ideologies led them to adopt contrary stances toward how the phonograph's affordances interacted with students' bodies (Weidman 2006).

\section{REMEDIATION}

In the ethnographic examples discussed here, there exists a comparison, tacit or explicit, between a medium and all others available in that media ecology. People on the ground put the media ideologies and media practices associated with a recently introduced channel of communication in dialogue with the ideologies and practices of other older channels-what Bolter \& Grusin call remediation (Bolter \& Grusin 1999, Kittler 1999). Thus how Kayapo people will adopt video cameras is shaped in part by their understanding of radio broadcasting and copresent speech. They value film's ability to represent what is real through repetition in part because radio or vocal sound's ephemerality does not easily allow for the kinds of repetition that Kayapo value as crucial for substantiating efforts to establish social unities (Turner 2002). Bauman (2010b) explores how performers consciously experiment with translating the copresent performance forms with which they and their audiences are familiar to the constraints of a new medium, aiming for continuity between forms. Continuity is not always desired. Reed, who offers one of the earliest ethnographic studies of bloggers, points out that blogs functioned for the authors as a genre of self-fashioning in contradistinction to the genre repertoire they were already producing at work in the form of spreadsheets, memos, and so on (Reed 2005; for definition of genre repertoire, see Orlikowski \& Yates 1994; see Hull 2012 for rich ethnographic examples of bureaucratic genre repertoires). In short, it can be precisely the ways in which a new medium can seem to establish presence in the already established terms of previously used media that determine when telepresence is seen as contiguous with offline life (Ito \& Okabe 2005, p. 8). At its heart, remediation is fundamentally about coordinating people's chronotopic experiences of media, interweaving how people construct time-space relationships around media that produce shared understandings of oldness, newness, and nostalgia (Acland 2006, Fisher 2016, Moskowitz 2015, Vokes \& Pype 2016).

How a medium is located in a media ecology is sometimes open for negotiation through linguistic practices. Jones \& Schieffelin (2009) argue that US college students are increasingly using the quotative "like" while instant messaging in an attempt to redefine where instant messaging falls on a continuum between oral and written exchanges, aligning these conversations more with orality. To understand how one medium accrues certain media ideologies and practices, one must 
analyze the other media it remediates as well as the linguistic practices used to position the medium within the broader media ecology.

Linguistic anthropologists have long known that the distinction between mediated and unmediated is one to be made by people on the ground and not by analysts. This position undercuts a common analytical move of media scholars. By taking copresence to be one channel among many, analysts can explore how different qualities_-directness, formality, politeness, sonic resonanceget aligned with different channels and not always in expected ways (Chumley \& Harkness 2013, Miller 2007). Kunreuther's analysis of FM radio in Nepal illustrates how productive it can be to refuse this distinction and, indeed, to refuse imposing the analyst's own classification of media in general. She describes how in-person communication is taken to be more indirect than FM radio, in part because Nepalese view the voice as offering a transparent lens into a new form of subject: the conscious interior self. At the same time, by refusing to classify all radio broadcasts as the same media, Kunreuther (2014) was able to document how FM radio is viewed as a radically new and politically transformative medium, as opposed to the government-sponsored radio broadcasts on AM radio. In Nepal, tracking how people interweave and contrast their semiotic ideologies of all that composes their media ecologies reveals the conceptual resources that people have for engaging with political and epistemic shifts. Analyzing one form of media should always take into account how this medium is situated within a media ecology and range of communicative practices, differentiated by culturally specific semiotic ideologies of both communication in general and different channels' affordances specifically.

In studying remediation, some anthropologists have been influenced by Frederich Kittler's work; Kittler is a German media theorist whose starting point is the strong assumption that people become social and historical beings by virtue of how their bodies combine with their prosthetics (media technologies) to allow them to receive and produce communication (Kittler 1999). Thus every time a new medium is introduced into a community's media ecology, people in that community become ontologically different beings than who they were before. From this perspective, the aforementioned Kayapo are Others to Luso-Brazilians because they have different historical experiences of media ecologies. This is a medium-specific take on ontological difference.

Anthropologists have drawn inspiration from the fact that for Kittler, the materiality of communication is central; each technology is different from the others in terms of both media's concrete materiality and how this materiality is interpreted from a culturally specific vantage point (Barker 2008, Kunreuther 2006, Mitchell 2009, Weidman 2003). The way a gramophone reconfigures people's relationships to sound and voices is substantively different from how film reconfigures people's relationship to images and bodies (Kittler 1999). Larkin, among others, has also demonstrated that not only is each medium's material form different, but also the infrastructures that support and maintain these media are specific to both country and class. Kittler's emphasis on media storage needs to be supplemented by wide-ranging attention to media access, maintenance, and repair (Kuipers et al. 2015, Larkin 2004, Poggiali 2016).

\section{MEDIALITY}

If remediation encourages a scholarly focus on how people's responses to a medium depend in part on comparisons with all other media available, mediality - that is, the condition of being a medium-encourages a scholarly exploration of how people develop with others certain presuppositions about what is entailed when communicating through a "new" form of media. Here, I am building on Eisenlohr's argument that mediality is foundationally involved when either media or language "oscillate between highly obvious, visible and creative roles on one hand, and their tendency to vanish in the act of mediation on the other hand" (Eisenlohr 2011b, p. 267). Eisenlohr

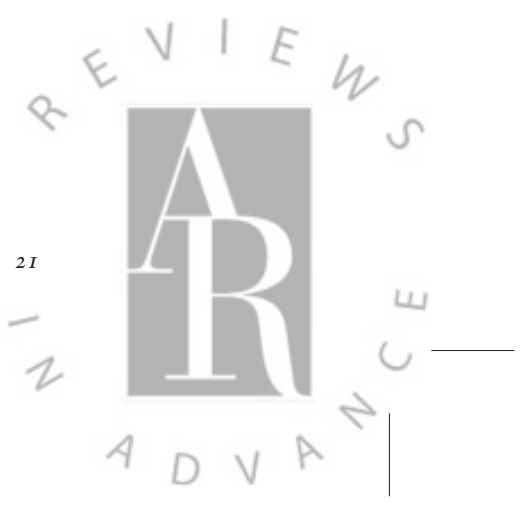


explains that for either media or language to go unnoticed, there must be a widespread agreement among participants about how the channel should function. Thus one way in which media is experienced as new is that it cannot oscillate easily between appearing to have a creative role and being transparent. Part of the work of making new media into commonplace and embedded media lies in developing social strategies and coordinated understandings so that the medium can oscillate (Meyer 2011).

Considerable social labor goes into making a medium appear transparent. A number of scholars show how complicated it can be to create widespread agreement around which genres or registers are most appropriate for a specific media (Barber 2012, Cole \& Pellicer 2012, Ferrara et al. 1991, Squires 2010). Attaching registers to new media in a way that others view as appropriate can have the effect of keeping the medium visible throughout the interaction, as Spitulnik shows in her analysis of how the radio was a "conduit and catalyst for talk about modernity" in colonial Zambia (Spitulnik 1998, p. 81). Often when a medium is first introduced, there is a tremendous amount of experimentation with genres as people transfer genres to this new medium as well as invent new genres. Barber (2012) describes prolific experimentations with genres when printing presses first circulated among Yoruba in Nigeria at the turn of the twentieth century; a single text often contained rapid juxtapositions of oral narrative styles and innovative techniques for organizing information. In these moments, the effervescence of genre experiments ensures that the medium stays visible throughout. As long as genres and registers are unstably attached to certain media, the very fact that a medium is a new channel of communication will stay in the foreground of any communicative interaction. Not only newness has this effect. Strassler (2009), in her discussion of how money functions as a medium, argues that in moments of financial crisis in Indonesia, money stops oscillating and becomes a consistently visible conduit for government authority. The images of state power on every bill and coin no longer vanish into the background (Strassler 2009, p. 72).

Just as mediality is an issue when people seek to attach genres and registers to a medium, mediality also comes to the fore during media switching, when participants choose to change the medium they are using to communicate (Gershon 2010a). Media switching can transform what language, images, participant roles, and voice can accomplish in an interaction (for language: Cole \& Pellicer 2012, Eisenlohr 2011b; for images: Strassler 2014, Thorner 2010; for participant roles: Inoue 2011, Manning 2013, Nozawa 2013; for voice: Fisher 2016, Harkness 2014, Kunreuther 2014, Mitchell 2009, Weidman 2006). Media switching often involves entextualization because texts or utterances are removed from a conversation shaped partially by the medium in which communication is taking place and then taken to another medium (see Spitulnik 1996). In analyzing a video game inspired by a Serbian democracy movement, Greenberg (2012) notes that the game designers remove contextually specific markers and the semiotic ambiguity of the mass demonstrations that the designers were referencing, and they did so to support a putatively universal and inevitable set of democratic principles. Entextualization across channels, in this instance, serves to validate some democratic procedures as supposedly free of context and erase others (Greenberg 2012). In general, in transferring knowledge or utterances across media, often the success or failure of this switch comes from the shared presuppositions that people have about media, and mediality leaps to the fore.

\section{MEDIATORS}

New media are inevitably transforming participant frameworks through new technological structures and, in the process, are also creating mediators and other roles that had not previously existed, such as telephone operators (Fischer 1992) or radio music editors (Kaplan 2012). These new roles are often linked to the mediality of communication and emergent media ideologies in complex

Gershon 
ways. Inoue (2011) discusses how stenographers emerged as new mediators in the Japanese parliament, reconfiguring how political speech was recorded as Japanese politicians began to fashion a putatively modern nation. She argues that stenographers came to be seen as transparent and objective vehicles for capturing the immediacy of political speech, itself viewed as a newly available genre in modernizing Japan at the turn of the twentieth century (Inoue 2011).

Yet these new roles are not occupied only by humans; technologies and many nonhumans also have newly fashioned roles in communicative interactions (Helmreich 2007, Manning 2013, Nozawa 2013). Nozawa (2013) points out that animated characters ubiquitous in Japan now function to facilitate communication by constituting "an interface of objects and spaces that relays signs between other semiotic actants” (p. 6). Similarly, Manning (2013) argues that avatars in the game Ryzom are divided between those that are actively controlled (and vocal) and those that are passively controlled (and silent) — a distinction that is significant when players are determining whether an avatar is a human or a thing within the game world. Or, to take this a step further, as Helmreich points out in his work on underwater and outer space sound, new technologies of audition change what is possible for humans and nonhumans to "hear." These new configurations of human/nonhuman actants that make and sense sound transform what can count as participant structures and presence (Helmreich 2007).

Different channels decompose participant roles in new ways, allowing for new participant roles to emerge and for role fractions to be distributed in new ways. When Bollywood started making films in the 1930s, the language in which the films would be made was up for grabs at every stage of production, leading to scripts getting written in English by a screenwriter and then translated into Hindi by a "dialogue writer" (a role created for this task) (Ganti 2016, p. 121). Similarly, new occupations emerge alongside introduced media. Once literacy became widespread yet unequally distributed in rural Nepal, authors began to make money by writing guidebooks for how to write love letters (Ahearn 2001). In Bolivia, indigenous language radio stations began to hire Aymara language authorities to vet scripts to ensure that the Aymara spoken on the radio programs is free of Spanish loanwords (Swinehart 2012).

New types of role fractions also become possible when a medium introduces novel participant structures. For example, a classical music student with a phonograph in India is decomposed into a performer playing alongside and coordinating with a machine, both listener and participant, rather than simply repeating phrases introduced by the teacher in copresent learning contexts (Weidman 2006). In short, newness emerges alongside new participant roles available both for humans and for nonhumans in ways that often encourage participants to reflect on various aspects of identity.

\section{OLD AND NEW IDENTITIES}

Since Benedict Anderson made the argument that print capitalism led to national identities, a prevalent strategy for analyzing the social change that new media supposedly introduces is to look at the emergence of novel identities that accompany the introduction of new technology. A substantial literature in linguistic anthropology, in dialogue with Silverstein (2000), complicates Anderson's causal view that new communicative technologies inspire people in straightforward ways to view the world through predictably discernible new frameworks and, thus, to adopt new identities (Anderson 1999, Silverstein 2000). Silverstein and others argue that when a medium is first introduced, how the medium structures experiences of time and concepts of social unity is not a given. It requires a tremendous amount of pedagogical labor in commonplace interactions in addition to institutionalized ones to convince large swaths of people to share common beliefs about which aspects of a medium's technological structure matters for a given communicative act. That is, Anderson's argument short-circuits all the labor that must take place for newspapers and

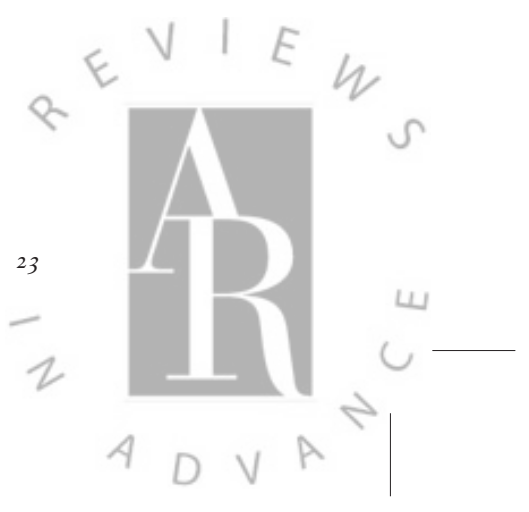


novels to engender national, diasporic, or ethnic identities when these materials circulate among reading publics (see also Cody 2013, Graber 2012, Manning 2002).

Several recent ethnographies have addressed the multiple types of coordination necessary to fashion collective identities, setting new technologies in relation to already circulating ideas about modernity, diaspora, nationalism, cosmopolitanism, and globalization (Bate 2013, Handman 2013, Ito et al. 2010, Kunreuther 2014, Weidman 2006). Anthropologists have observed that when people are texting, rapid and deliberate switches between English and local languages can signal a new cosmopolitan identity-someone conversant with both global circuits and local strategies for construing value (McIntosh 2010, Swank 2014). Pype (2016) argues that the affordances of mobile phones-ID blocking and phone-specific pseudonyms - allow Congolese to mobilize wellestablished understandings of secrecy and concealment to circulate information as anonymous citizens (a category necessitated by government surveillance under a dictatorship) instead of using the more established categories of personhood enmeshed in multiple and complex social hierarchies.

The converse also takes place: People bring well-established understandings of identity to potentially transformative media, using these technologies' new participant structures to reassert social hierarchies and language ideologies (Baron 2002; Bauman 2010a,b; Queen 2004; Stæhr \& Madsen 2015; Yamaguchi 2013). Brink-Danan (2011) discusses how Internet forums become sites for conversing in Ladino as well as for demonstrating Ladino's vibrancy, despite scholarly claims that a Judeo-Spanish collectivity no longer exists. The newness of new media can be a resource for reasserting older identity forms, gaining tacit authority for these forms precisely because the forms are efficacious in these new channels.

Not all potential identities are equal in their political effect. In the contemporary moment, some scholars view it as urgent to ascertain how a neoliberal self is constituted and taught through technologies (Jones et al. 2015, Kunreuther 2010, Weidman 2014, Wilf 2016). In the process, they wish to specify what is distinctive about a neoliberal self as opposed to a broadly defined capitalist self. When scholars address this question by focusing on how communicative technologies are produced, they have found that neoliberal logics are often tightly interwoven with Silicon Valley-based approaches to creativity, risk, and failure (Jones et al. 2015, Wilf 2016). Dent (2012), taking another tact, explores how intellectual property piracy does not emerge as a salient category because of new technological capacities to copy. Instead it emerges when those in power respond to the risk inherent in the impossible neoliberal ideal that everyone be an entrepreneur by demarcating some entrepreneurs and entrepreneurial behaviors as legitimate and others as illegitimate (Dent 2012).

\section{DIRECTIONS FOR FUTURE RESEARCH}

Although there are many exciting developments at the intersection of linguistic anthropology and media anthropology, I conclude by sketching two especially promising new directions: an anthropologically inflected animation theory and a possible dialogue between science and technology studies and linguistic anthropology that builds on aforementioned critiques of Anderson. A nascent literature is taking up Silvio's (2010) suggestion that animation is increasingly replacing performance as a dominant trope for understanding how identities are produced through communicative channels under contemporary late capitalism (Manning 2013; Manning \& Gershon 2013; Nozawa 2013, 2016; Occhi 2012; Silvio 2010; for a discussion of how media ideologies and language ideologies intersect in Disney animation, see Lippi-Green 1997). Silvio suggests that participant structures, which had previously been understood largely through the lens of performance, might more productively be understood through the additional lens of animation. Performance, she argues, encourages participants to be attentive primarily to the relationship between actor and character, with an accompanying concern about when someone is acting

Gershon 
according to script or, instead, when someone is improvising. Animation, by contrast, focuses on how a unified character is produced through the labor of many (most literally, inkists, colorists, voice actors, and audience projection; see Irvine 1996) and thus encourages concerns about control versus free will as well as concerns about how precisely one can represent or speak for many in a given cultural context. Under performance, the actor-character dyad exists in part because of the willingness of many to labor in effaceable ways. This willingness enables the fundamental tension of performance to revolve around whether one is enacting social structure (is scripted) or one is enacting social transformation (is improvising). Animation refuses to ignore the labor on the part of many that produces any actor, bringing a basic tenet of actor-network theory into the social analysis performed on the ground. In doing so, animation encourages people to explore what is important about being alive as opposed to being programmable. Yet, the rise of animation does not lead to the wholesale replacement of performance as a trope; rather, Silvio (2010) proposes that in our present historical moment, they are co-constitutive.

In his study of Japanese voice actors, Nozawa (2016) shows how illuminating this focus on animation can be by arguing that it is more apt to view voice actors as engaged in ensoulment, which he defines as "processes of 'animation' that distribute and project life-forces, anima, onto various types of actants” (p. 173). Instead of artists viewing themselves as performers, Japanese voice artists' own social analysis is that they are animators (here both in Silvio's sense and in Goffman's sense), meant to be instruments themselves through which characters manifest themselves. The voice artist's media ideology is that the voice is no more a site of the authentic artist's self than the pen tracing the character's shape on top of a pencil outline is an instantiation of an artist's inner creative self. In short, Silvian animation theory provides another angle from which to understand how newness is constructed, offering the possibility that reflexive understandings of how one inhabits participant structures also require the types of coordination addressed above.

Along similar lines, scholars could fruitfully explore how some efforts to create standard media practices may be culturally or historically specific by creating a productive dialogue between the linguistic anthropological focus on coordination around new media discussed here, prior work on language standardization (Johnstone 2016, Kroskrity 2000), and science studies' analyses of standardization (Bowker \& Star 1999, Busch 2011, Lampland \& Star 2008, Timmermans \& Epstein 2010). Specifically, such research could yield comparative analyses that address whether different ways of organizing entities such as nations or markets $(a)$ encourage different techniques for standardizing communicative practices involving new media; $(b)$ focus on different practices to standardize; $(c)$ inspire different types of actors to be involved in standardizing; and $(d)$ foster attempts at standardization at different moments in people's adoption and use of new media. These comparisons could reveal how historically specific capitalist logics are naturalized through different strategies for standardizing users' practices around newly introduced media (Fischer 1992, Gershon 2017). By using coordination as a starting point, scholars can develop illuminating axes for comparison that may reveal the heterogeneity of social change.

\section{DISCLOSURE STATEMENT}

The author is not aware of any affiliations, memberships, funding, or financial holdings that might be perceived as affecting the objectivity of this review.

\section{ACKNOWLEDGEMENTS}

A number of people gave me very helpful editing suggestions on drafts of this review: Richard Bauman, Rosemary Coombes, Kira Hall, Stefan Helmreich, Laura Kunreuther, Paul Manning, James Slotta, and Matt Tomlinson. My thanks go especially to Giovanni Ricci for his assistance.

www.annualreviews.org • Language and the Newness of Media

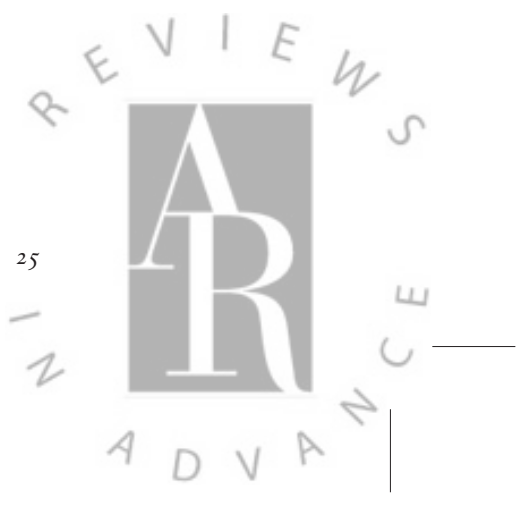




\section{LITERATURE CITED}

Acland C, ed. 2006. Residual Media. Minneapolis: Univ. Minn. Press

Agha A. 2003. The social life of cultural value. Lang. Commun. 23(3-4):231-73

Ahearn LM. 2001. Invitations to Love: Literacy, Love Letters and Social Change in Nepal. Ann Arbor: Univ. Mich. Press

Anderson B. 1999. Imagined Communities. London: Verso Press

Androutsopoulos J. 2014. Moments of sharing: entextualization and linguistic repertoires in social networking. 7. Pragmat. $73: 4-18$

Archambault JS. 2013. Cruising through uncertainty: cell phones and the politics of display and disguise in Inhambane, Mozambique. Am. Ethnol. 40(1):88-101

Barber K. 2012. Yorùbá Print Culture and the First Yoruba Novel: I.B. Thomas's 'Life Story of Me, Segilọla' and Other Texts. Leiden, Neth.: Brill

Barker J. 2008. Playing with publics: technology, talk and sociability in Indonesia. Lang. Commun. 28:127-42

Baron NS. 2002. Who sets e-mail style? Prescriptivism, coping strategies, and democratizing communication access. Inf. Soc. 18:403-13

Bate B. 2013. 'To persuade them into speech and action': vernacular oratory in a genealogy of the Tamil political. Comp. Stud. Soc. Hist. 55:142-66

Bauman R. 2010a. 'It's not a telescope, it's a telephone': encounters with the telephone on early commercial sound recordings. In Language Ideologies and Media Discourse: Texts, Practices, Politics, ed. S Johnson, T Milani, pp. 252-73. New York: Continuum

Bauman R. 2010b. The remediation of storytelling: narrative performance on early commercial sound recordings. In Telling Stories: Building Bridges Among Language, Narrative, Identity, Interaction, Society and Culture, ed. D Schiffrin, A De Fina, A Nylund, pp. 23-43. Washington, DC: Georgetown Univ. Press

Bauman R, Briggs CL. 1990. Poetics and performance as critical perspectives on language and social life. Annu. Rev. Anthropol. 19:59-88

Bolter J, Grusin R. 1999. Remediation: Understanding New Media. Cambridge, MA: MIT Press

Bowker GC, Star SL. 1999. Sorting Things Out: Classification and Its Consequences. Cambridge, MA: MIT Press

Briggs CL. 2011. On virtual epidemics and the mediatization of public health. Lang. Commun. 31:217-28

Brink-Danan M. 2011. The meaning of Ladino: the semiotics of an online speech community. Lang. Commun. 31:107-18

Bucholtz M, Hall K. 2005. Identity and interaction: a sociocultural linguistic approach. Discourse Stud. 7:585614

Busch L. 2011. Standards: Recipes for Reality. Cambridge, MA: MIT Press

Christensen TH. 2009. 'Connected presence' in distributed family life. New Media Soc. 11:433-51

Chumley LH, Harkness N. 2013. Qualia. Anthropol. Theory 13:3-11

Chun WHK, Keenan T, ed. 2006. New Media, Old Media: A History and Theory Reader. New York: Routledge

Cody F. 2013. The Light of Knowledge: Literacy Activism and the Politics of Writing in South India. Ithaca, NY: Cornell Univ. Press

Cole D, Pellicer R. 2012. Uptake (un)limited: the mediatization of register shifting in US public discourse. Lang. Soc. 41:449-70

Coleman EG. 2010. Ethnographic approaches to digital media. Annu. Rev. Anthropol. 39:487-505

Davis DZ, Boellstorff T. 2016. Compulsive creativity: virtual worlds, disability, and digital capital. Int. F. Commun. 10:2096-118

Deger J. 2013. The jolt of the new: making video art in Arnhem Land. Cult. Theory Crit. 54:355-71

Dent AS. 2012. Piracy, circulatory legitimacy, and neoliberal subjectivity in Brazil. Cult. Anthropol. 27:28-49

Doostdar A. 2004. 'The vulgar spirit of blogging': on language, culture, and power in Persian weblogestan. Am. Antbropol. 106:651-62

Eisenlohr P. 2010. Materialities of entextualization: the domestication of sound reproduction in Mauritian Muslim devotional practices. F. Linguist. Anthropol. 20:314-33

Eisenlohr P, ed. 2011a. Special issue: What is a medium? Theologies, technologies, and aspirations. Soc. Antbropol. 19(1)

Gershon 
Eisenlohr P. 2011b. Media authenticity and authority in Mauritius: on the mediality of language in religion. Lang. Commun. 31:266-73

Englund H. 2015. Multivocal morality: narrative, sentiment and Zambia's radio grandfathers. HAU: F. Ethnogr. 5:251-73

Ferrara K, Brunner H, Whittemore G. 1991. Interactive written discourse as an emergent register. Written Commun. 8:8-34

Fischer CS. 1992. America Calling: A Social History of the Telephone to 1940. Berkeley: Univ. Calif. Press

Fisher D. 2016. The Voice and Its Doubles: Media and Music in Northern Australia. Berkeley: Univ. Calif. Press

Ganti T. 2016. "No one thinks in Hindi here": language hierarchies in Bollywood. In Precarious Creativity: Global Media, Local Labor, ed. M Curtin, K Sanson, pp. 118-31. Berkeley: Univ. Calif. Press

Gershon I. 2010a. Breaking up is hard to do: media switching and media ideologies. 7. Linguist. Anthropol. 20:389-405

Gershon I. 2010b. Media ideologies: an introduction. 7. Linguist. Anthropol. 20:283-93

Gershon I. 2017. Down and Out in the New Economy: How People Find (or Don't Find) Work Today. Chicago: Univ. Chicago Press

Gibson JJ. 1979. The Ecological Approach to Visual Perception. New York: Taylor and Francis Group

Gitelman L. 2006. Always Already New: Media, History, and the Data of Culture. Cambridge, MA: MIT Press

Goffman E. 1974. Frame Analysis: An Essay on the Organization of Experience. New York: Harper and Row

Goffman E. 1981. Forms of Talk. Oxford, UK: Blackwell

Graber K. 2012. Public information: the shifting roles of minority language news media in the Buryat territories of Russia. Lang. Commun. 32:124-36

Greenberg J. 2012. Gaming the system: semiotic indeterminacy and political circulation in the new age of revolution. Lang. Commun. 32:372-85

Gregg M. 2011. Work's Intimacy. London: Polity Press

Hagood M. 2011. QuietComfort: noise, otherness, and the mobile production of personal space. Am. Q. 63:573-89

Handman C. 2013. Text messaging in Tok Pisin: etymologies and orthographies in cosmopolitan Papua New Guinea. Cult. Theory Crit. 54:265-84

Harkness N. 2014. Songs of Seoul: An Ethnography of Voice and Voicing in Christian South Korea. Berkeley: Univ. Calif. Press

Hull MS. 2012. Government of Paper: The Materiality of Bureaucracy in Urban Pakistan. Berkeley: Univ. Calif. Press

Helmreich S. 2007. An anthropologist underwater: immersive soundscapes, submarine cyborgs, and transductive ethnography. Am. Ethnol. 34:621-41

Henkin DM. 2006. The Postal Age: The Emergence of Modern Communication in Nineteenth-Century America. Chicago: Univ. Chicago Press

Hutchby I. 2001. Technologies, texts and affordances. Sociology 35:441-56

Inoue M. 2011. Stenography and ventriloquism in late nineteenth century Japan. Lang. Commun. 31:181-90

Irvine JT. 1996. Shadow conversations: the indeterminacy of participant roles. In Natural Histories of Discourse, ed. M Silverstein, G Urban, pp. 131-59. Chicago: Univ. Chicago Press

Ito M, Baumer S, Bittanti M, boyd d, Cody R, et al. 2010. Hanging Out, Messing Around, and Geeking Out: Kids Living and Learning with New Media. Cambridge, MA: MIT Press

Ito M, Okabe D. 2005. Technosocial situations: emergent structuring of mobile e-mail use. In Personal, Portable, Pedestrian: Mobile Phones in Fapanese Life, ed. M Ito, D Okabe, M Matsuda, pp. 257-73. Cambridge, MA: MIT Press

Jaffe A, ed. 2009. Stance: Sociolinguistic Perspectives. Oxford, UK: Oxford Univ. Press

Jakobson R. 1960. Closing statements: language and poetics. In Style in Language, ed. TA Sebeok, pp. 350-77. New York: Wiley

Johnstone B. 2016. The sociolinguistics of globalization: standardization and localization in the context of change. Annu. Rev. Linguist. 2:349-65

Jones GM, Schieffelin BB. 2009. Enquoting voices, accomplishing talk: uses of be + like in instant messaging. Lang. Commun. 29:77-113

www.annualreviews.org • Language and the Newness of Media

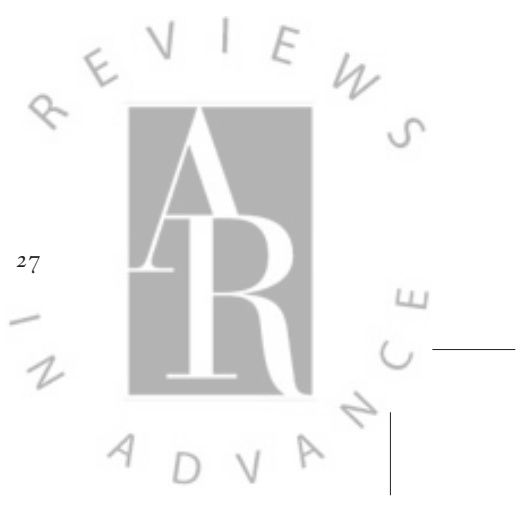


Jones GM, Semel B, Le A. 2015. “There's no rules. It's hackathon.”: negotiating commitment in a context of volatile sociality. F. Linguist. Anthropol. 25:322-45

Jones RH. 2009. Dancing, skating and sex: action and text in the digital age. F. Appl. Linguist. Prof. Pract. 6:283-302

Kaplan D. 2012. Editing the nation: how radio engineers encode Israeli national imaginaries. In Radio Fields: Anthropology and the Wireless Sound in the 21st Century, ed. L Bessire, D Fisher, pp. 89-107. New York: N. Y. Univ. Press

Keane W. 2003. Semiotics and the social analysis of material things. Lang. Commun. 23:409-25

Keane W. 2013. On spirit writing: materialities of language and the religious work of transduction. $\mathcal{F} . R$. Anthropol. Inst. 19:1-17

Keating E, Mirus G. 2003. American Sign Language in virtual space: interactions between deaf users of computer-mediated video communication and the impact of technology on language practices. Lang. Soc. 32:693-714

Kittler FA. 1999. Gramophone, Film, Typewriter, transl. G Winthrop-Young, M Wutz. Stanford, CA: Stanford Univ. Press. From German

Kroskrity P, ed. 2000. Regimes of Language: Ideologies, Polities, and Identities. Santa Fe, NM: Sch. Am. Res. Press

Kuipers J, Bell JA, Dent A, Kemble A, Kobak B. 2015. Fixing Connections: Language, Culture and Cell Phone Use Among High School and University Students in Washington, D.C. David Skomp Disting. Lect. Ser. Anthropol. Bloomington: Indiana Univ.

Kunreuther L. 2006. Technologies of the voice: FM radio, telephone, and the Nepali diaspora in Kathmandu. Cult. Anthropol. 21:323-53

Kunreuther L. 2010. Transparent media: radio, voice, and ideologies of directness in postdemocratic Nepal. 7. Linguist. Anthropol. 20:334-51

Kunreuther L. 2014. Voicing Subjects: Public Intimacy and Mediation in Kathmandu. Berkeley: Univ. Calif. Press Lampland M, Star SL, eds. 2008. Standards and Their Stories: How Quantifying, Classifying, and Formalizing Practices Shape Everyday Life. Ithaca, NY: Cornell Univ. Press

Lange PG. 2014. Kids on YouTube: Technical Identities and Digital Literacies. Walnut Creek, CA: Left Coast Press

Larkin B. 2004. Degraded images, distorted sounds: Nigerian video and the infrastructure of piracy. Public Cult. 16:289-314

Larkin B. 2008. Signal and Noise: Media, Infrastructure, and Urban Culture in Nigeria. Durham, NC: Duke Univ. Press

Laurier E. 2001. Why people say where they are during mobile phone calls. Environ. Plan. D: Soc. Space 19:485-504

Lave J, Wenger E. 1991. Situated Learning: Legitimate Peripheral Participation. New York: Cambridge Univ. Press

Lemon A. 1998. "Your eyes are green like dollars": counterfeit cash, national substance, and currency apartheid in 1990s Russia. Cult. Antbropol. 13:22-55

Lempert M, Silverstein M. 2012. Creatures of Politics: Media, Message, and the American Presidency. Bloomington, IN: Indiana Univ. Press

Levinson S. 1988. Putting linguistics on a proper footing: explorations in Goffman's concepts of participation. In Erving Goffman: An Interdisciplinary Appreciation, ed. P Drew, A Wootton, pp. 161-227. Oxford, UK: Polity Press

Lippi-Green R. 1997. English with an Accent: Language, Ideology and Discrimination in the United States. New York: Routledge

Manning HP. 2002. English money and Welsh rocks: divisions of language and divisions of labor in nineteenthcentury Welsh slate quarries. Comp. Study Soc. Hist. 44:481-510

Manning P. 2013. Altaholics anonymous: on the pathological proliferation of parasites in massively multiple online worlds. Semiot. Rev. 1: https://www.semioticreview.com/ojs/index.php/sr/article/view/30

Manning P, Gershon I. 2013. Animating interaction. HAU: f. Ethnogr. Theory 3:107-37

Marvin C. 1988. When Old Technologies Were New: Thinking about Electric Communication in the Nineteenth Century. New York: Oxford Univ. Press

Gershon 
Mazzarella W.2010. Beautiful balloon: the digital divide and the charisma of new media.Am. Ethnol.37(4):783804

McIntosh J. 2010. Mobile phones and Mipoho's prophecy: the powers and dangers of flying language. Am. Ethnol. 37:337-53

Mendoza-Denton N. 2011. The semiotic hitchhiker's guide to creaky voice: circulation and gendered hardcore in a Chicana/o gang persona. 7. Linguist. Anthropol. 21:261-80

Meyer B. 2011. Mediation and immediacy: sensational forms, semiotic ideologies and the question of the medium. Soc. Antbropol. 19:23-39

Miller F. 2007. The Moral Resonance of Arab Media: Audiocassette Poetry and Culture: Audiocassette Culture and Poetry in Yemen. Cambridge, MA: Harvard Univ. Press

Mitchell L. 2009. Language, Emotion, and Politics in South India: The Making of a Mother Tongue. Bloomington, IN: Indiana Univ. Press

Moskowitz ML. 2015. From Mao Zedong to Michael Jackson: revisualizing culture and history in the YouTube age. China Inf. 29(3):309-32

Nardi B. 2015. Virtuality. Annu. Rev. Antbropol. 44:15-31

Nardi BA. 2005. Beyond bandwidth: dimensions of connection in interpersonal communication. Comput.Supported Cooperative Work 14:91-130

Nozawa S. 2013. Characterization. Semiot. Rev. 3: https://www.semioticreview.com/ojs/index.php/sr/ article/view/16

Nozawa S. 2016. Ensoulment and effacement in Japanese voice acting. In Media Convergence in fapan, ed. PW Galbraith, JG Karlin, pp. 169-99. New Haven, CT: Kinema Club

Occhi DJ. 2012. Wobbly aesthetics, performance, and message: comparing Japanese Kyara with their anthropomorphic forebears. Asian Ethnol. 71(1):109-32

Oosterbaan M. 2011. Virtually global: online evangelical cartography. Soc. Anthropol. 19(1):56-73

Orlikowski WJ, Yates J. 1994. Genre repertoire. Adm. Sci. Q. 39(4):541-74

Peters JD. 1999. Speaking into the Air: A History of the Idea of Communication. Chicago: Univ. Chicago Press

Philips S. 1972. Participant structures and communicative competence: Warm Springs children in community and classroom. In Functions of Language in the Classroom, ed. CB Cazden, VP John, D Hymes, pp. 270-394. New York: Teach. Coll. Press

Poggiali L. 2016. Seeing (from) digital peripheries: technology and transparency in Kenya's Silicon Savannah. Cult. Antbropol. 31(3):387-411

Pype K. 2016. "[Not] talking like a Motorola": mobile phone practices and politics of masking and unmasking in postcolonial Kinshasa. 7. R. Anthropol. Inst. 22(3):633-52

Queen R. 2004. 'Du hast jar keene Ahnung': African-American English dubbed into German. F. Sociolinguist. $8(4): 515-37$

Raclaw J, Robles JS, DiDomenico SM. 2016. Providing epistemic support for assessments through mobilesupported sharing activities. Res. Lang. Soc. Interact. 49(4):362-79

Reed A. 2005. 'My blog is me': texts and persons in UK Online Journal Culture (and anthropology). Ethnos 70:220-42

Ribak R, Rosenthal M. 2015. Smartphone resistance as media ambivalence. FirstMonday 20(11): http:// firstmonday.org/ojs/index.php/fm/article/view/6307/5136

Schulthies B. 2014. Scripted ideologies: orthographic heterogeneity in online Arabics. Al-'Arabiyya, f. Am. Assoc. Teach. Arabic 47:41-56

Sherouse P. 2014. Hazardous digits: telephone keypads and Russian numbers in Tbilisi, Georgia. Lang. Commun. 37:1-11

Silverstein M. 1979. Language structure and linguistic ideology. In The Elements: A Parasession on Linguistic Units and Levels, ed. PR Cline, WF Hanks, CL Hofbauer, pp. 193-247. Chicago: Chicago Linguist. Soc. Silverstein M. 2000. Whorfianism and the linguistic imagination of nationality. See Kroskrity 2000, pp. 85-138 Silverstone R. 1999. What's new about new media? New Media Soc. 1:10-12

Silvio T. 2010. Animation: the new performance? F. Linguist. Anthropol. 20(2):422-38

Spitulnik D. 1996. The social circulation of media discourse and the mediation of communities. F. Linguist. Anthropol. 6(2):161-87

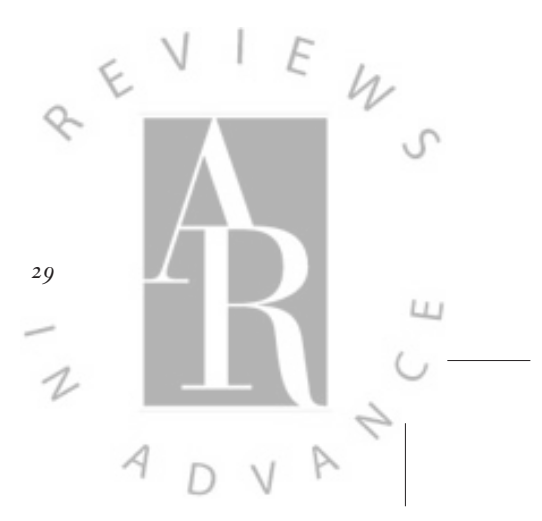


Spitulnik D. 1998. Mediated modernities: encounters with the electronic in Zambia. Vis. Anthropol. Rev. 14(2):63-84

Spyer P. 2001. The Cassowary will (not) be photographed: the "primitive," the "Japanese," and the elusive "sacred" (Aru, Southeast Moluccas). In Religion and Media, ed. H de Vries, S Weber, pp. 304-20. Stanford, CA: Stanford Univ. Press

Squires L. 2010. Enregistering Internet language. Lang. Soc. 39(4):457-92

Stæhr A, Madsen LM. 2015. Standard language in urban rap: social media, linguistic practice and ethnographic context. Lang. Commun. 40:67-81

Sterne J. 2003. The Audible Past: Cultural Origins of Sound Reproduction. Durham, NC: Duke Univ. Press

Sterne J. 2012. MP3: The Meaning of a Format. Durham, NC: Duke Univ. Press

Strassler K. 2009. The face of money: currency, crisis, and remediation in post-Suharto Indonesia. Cult. Antbropol. 24(1):68-103

Strassler K. 2014. Seeing the unseen in Indonesia's public sphere: photographic appearances of a spirit queen. Comp. Stud. Soc. Hist. 56(1):98-130

Strathern M. 2014. Innovation or replication? Crossing and criss-crossing in social science. Arts Humanit. Higher Educ. 13(1-2):62-76

Street BV. 1984. Literacy in Theory and Practice. Cambridge, UK: Cambridge Univ. Press

Swank H. 2014. Rewriting Shangri-La: Tibetan Youth, Migrations and Literacies in McLeod Ganj, India. Leiden, Neth.: Brill

Swinehart KF. 2012. Metadiscursive regime and register formation on Aymara radio. Lang. Commun. 32:102_ 13

Tannen D. 2013. The medium is the metamessage: conversational style in social media interaction. In Discourse 2.0: Language and New Media, ed. D Tannen, AM Trester, pp. 99-118. Washington, DC: Georgetown Univ. Press

Taylor J. 2009. "Speaking shadows": a history of the voice in the transition from silent to sound film in the United States. 7. Linguist. Anthropol. 19(1):1-20

Thorburn D, Jenkins H, eds. 2003. Retbinking Media Change: The Aesthetics of Transition. Cambridge, MA: MIT Press

Thorner S. 2010. Imagining an indigital interface: Ara Irititja indigenizes the technologies of knowledge management. Collections 6(3):125-46

Timmermans S, Epstein S. 2010. A world of standards but not a standard world: toward a sociology of standards and standardization. Annu. Rev. Sociol. 36:69-89

Turner T. 2002. Representation, politics, and cultural imagination in indigenous video: general points and Kayapo examples. In Media Worlds: Antbropology on New Terrain, ed. F Ginsburg, L Abu-Lughod, B Larkin, pp. 75-89. Berkeley: Univ. Calif. Press

Umble DZ. 2000. Holding the Line: The Telephone in Old Order Mennonite and Amish Life. Baltimore, MD: Johns Hopkins Press

Urban G. 2001. Metaculture: How Cultures Moves Through the World. Minneapolis: Univ. Minn. Press

Vokes R, Pype K. 2016. Chronotopes of media in sub-Saharan Africa. Ethnos pp. 1-10

Walton S, Jaffe A. 2011. "Stuff white people like": stance, class, race, and Internet commentary. In Digital Discourse: Language in the New Media, ed. C Thurlow, K Mroczek, pp. 199-219. Oxford, UK: Oxford Univ. Press

Weidman A. 2003. Gender and the politics of voice: colonial modernity and classical music in South India. Cult. Anthropol. 18(2):194-232

Weidman A. 2014. Neoliberal logics of voice: playback singing and public femaleness in South India. Cult. Theory Crit. 55(2):175-93

Weidman AJ. 2006. Singing the Classical, Voicing the Modern: The Postcolonial Politics of Music in South India. Durham, NC: Duke Univ. Press

Weilenmann A. 2003. "I can't talk now, I'm in a fitting room": formulating availability and location in mobile phone conversations. Environ. Plan. A 35:1589-606

Wilf E. 2016. The post-it note economy: understanding post-Fordist business innovation through one of its key semiotic technologies. Curr. Anthropol. 57:732-60

Gershon 
Wilson SM, Peterson LC. 2002. The anthropology of online communities. Annu. Rev. Anthropol. 31:449-67 Woolard KA, Schieffelin BB. 1994. Language ideology. Annu. Rev. Anthropol. 23:55-82

Wortham S. 2003. Accomplishing identity in participant-denoting discourse. 7. Linguist. Anthropol. 13:189210

Yamaguchi M. 2013. Reconsidering communicative competence in Web 2.0 environments: "Asians in the library" and four parodic responses on YouTube. Lang. Commun. 33(4, pt. A):376-89

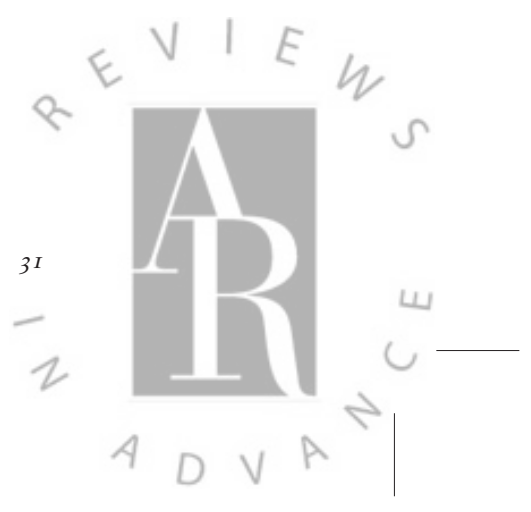

